Enant i o- sel ect i ve reduct i on of the fl ower ing rel at ed compound KODA and its anal ogues in Pharbi tis ni I cv. Vi ol et

\begin{tabular}{|c|c|}
\hline 著者 & $\begin{array}{l}\text { Mur at a Ar i aki, Kai Kenj i, Tsut sui Ken, } \\
\text { Takeuchi Jun, Todor oki Yasushi, Fur i hat a } \\
\text { Kazuo, Yokoyana M neyuki , Bal der mann Susanne, } \\
\text { Wat anabe Naohar u }\end{array}$ \\
\hline $\begin{array}{l}\text { journal or } \\
\text { publ i cat i on title }\end{array}$ & Tet r ahedr on \\
\hline vol une & 68 \\
\hline nunber & $27-28$ \\
\hline page $r$ ange & $5583-5589$ \\
\hline year & 2012-07-08 \\
\hline 出版者 & El sevi er \\
\hline 権利 & $\begin{array}{l}\text { Copyr i ght ( C) } 2012 \text { El sevi er Lt d. Al I right s } \\
\text { reser ved. }\end{array}$ \\
\hline URL & ht t p: //hdl . handl e. net /10297/6742 \\
\hline
\end{tabular}




\section{Graphical Abstract}

To create your abstract, type over the instructions in the template box below.

Fonts or abstract dimensions should not be changed or altered.

\section{Enantio-selective reduction of the flowering}

Leave this area blank for abstract info.

related compound KODA and its analogues

in Pharbitis nil cv. Violet

Murata, A.; Kai, K.; Tsutsui, K.; Takeuchi, J.; Todoroki, Y.; Furihata, K.; Yokoyama, M.; Baldermann, S.;

Watanabe, N. $\quad$ Shizuoka University, 836 Ohya, Suruga-ku, Shizuoka 422-8529, Japan

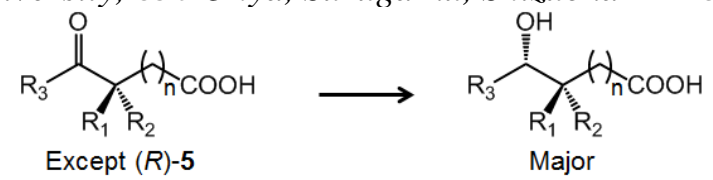

$\mathrm{R}_{1}, \mathrm{R}_{2}:(R)-1-6=\mathrm{OH}, \mathrm{H} ;(\mathrm{S})-1-6=\mathrm{H}, \mathrm{OH} ; \mathbf{7 - 1 0}=\mathrm{H}, \mathrm{H}$

$\mathrm{R}_{3}: 1-8=>9-10=\longrightarrow$

$n=3: 5,6 ; n=5: 3,4 ; n=7: 1,2,7,8,9,10$ 


\title{
Enantio-selective reduction of the flowering related compound KODA and its analogues in Pharbitis nil cv. Violet
}

\author{
Ariaki Murata ${ }^{a}$, Kenji Kai ${ }^{b}{ }^{\dagger}{ }^{\dagger}$ Ken Tsutsui ${ }^{a}$, Jun Takeuchi ${ }^{a}{ }^{a}$, Yasushi Todoroki ${ }^{a}$, Kazuo Furihata ${ }^{c}$, Mineyuki \\ Yokoyama, Susanne Baldermann ${ }^{\mathrm{a}}$, Naoharu Watanabe \\ ${ }^{a}$ Graduate School of Science and Technology, Shizuoka University, 836 Ohya, Suruga-ku, Shizuoka 422-8529, Japan \\ ${ }^{\mathrm{b}}$ Life and Environmental Sciences, Oosaka PrefectureUniversity, 1-1 Gakuen-cho, Nakaku, Sakai,Osaka 599-8531, Japan \\ ${ }^{\mathrm{c}}$ Graduate School of Agricultural and Life Sciences, The University of Tokyo, 1-1-1 Yayoi, Bunkyou-ku, Tokyo 113-8657, Japan \\ ${ }^{\mathrm{d}} H \& B C$ Research Center, Shiseido Co.Ltd., 2-12-1 Fukuura, Kanazawa-ku, Yokohama 236-8643, Japan
}

\section{ARTICLE INFO}

ABSTRACT

\section{Article history:}

Received

Received in revised form

Accepted

Available online

\section{Keywords}

Enantio-selective reduction

Lemna paucicostata

Flowering

Oxylipins

Pharbitis nil cv. Violet

\begin{abstract}
Plant oxylipins are an important class of signaling molecules in plants. The cyclic adducts of epinephrine or norepinephrine with the naturally occurring oxylipin (12Z,15Z)-9-hydroxy-10oxo-octadeca-12,15-dienoic acid (KODA, 1) or its synthetic analogues (2-6) have been reported to possess flower-inducing activity towards Lemna paucicostata. By in vivo and in vitro experiments with seedlings of Pharbitis nil cv. Violet carbonyl groups of the $\alpha$-ketols (1 and 3) and the ketones (7 and 9) were enantio-selectively reduced to give their corresponding vicinal diols (2 and 4) and alcohols (8 and 10). The stereo-chemistry at the oxymethine carbon was determined based on the long-range C-H coupling constants and the modified Mosher's method. Orientation of the adjacent hydroxyl group in (1 and 3) did not affect the enantioselectivity, whereas the conversion was slightly affected and higher yields were obtained with the $R$ enantiomers of the $\alpha$-ketols.
\end{abstract}

\section{Introduction}

KODA (1) was isolated as stress-mediated compound from Lemna paucicostata. The reaction products of $\mathbf{1}$ with norepinephrine and epinephrine showed strong flower-inducing activities towards Lemna. ${ }^{1,2} \mathbf{1}$ has been also identified in the leaves of Pharbitis nil cv. Violet ${ }^{3}$ and in immature flower buds of Dianthus caryophyllus L., Dendranthema grandiflorum Kitam, and Eustoma russellianum Griseb. ${ }^{4}$ P. nil, an well-known model plant for flowering-studies, is classified as a short-day plant which develops flower buds when cotyledons of 4- to 5-days old seedlings are exposed to a single $16 \mathrm{~h}$ dark period. ${ }^{4}$ We have earlier reported that the endogenous level of $\mathbf{1}$ in cotyledons of $P$. nil seedlings sharply increased when the seedlings were grown under the continuous dark conditions for $16 \mathrm{~h}$, and dropped rapidly to the basal level by an exposure of light at the end of the flower-inducing dark period. Flower bud formation was also correlated with elevated levels of 1 within $11 \mathrm{~h}$ to $16 \mathrm{~h}$ following the start of inductive dark period. ${ }^{4}$ This transient accumulation of 1 was not observed when seedlings were grown under continuous light. ${ }^{4}$ Little is known about chemical changes in plants during the exposure to flower-inductive photoperiod and points to a hypothesis of possible role of $\mathbf{1}$ in the flowering of $P$. nil as well as Lemna. Exogenously applied $\mathbf{1}$ did not induce the flowering in $P$. nil, however, it promoted the formation of flower buds even though the plants were exposed to shorter inductive dark periods. 1 is metabolized via two main reactions, namely $\alpha$-ketol reduction and $\beta$-oxidation of straight-chain acids in Lemna, ${ }^{5} P$. nil, ${ }^{6}$ and Citrus unshiu (unpublished) (Fig. 1). These results were revealed by feeding experiments of $\left[\mathrm{U}-{ }^{13} \mathrm{C}\right]-1$ to these plants.

We identified 2-6 as endogenous metabolites of $\mathbf{1}$ in these plants by LC-MS and NMR. ${ }^{6}$ These pathways seemed to be important to regulate flowering in $P$. nil, because the metabolites 2-6 with norepinephrine exhibited lower flower inducing activities. However the enantio-selectivity of the keto-reduction of $\mathbf{1}, \mathbf{3}$, and 5 was not clear. In this study, we have determined the absolute configuration of these metabolites, and demonstrated the enantio- selectivity of the reduction. We also analyzed substrate selectivity of the $P$. nil reductases towards $\mathbf{1}$ and its synthetic analogues by in vivo and in vitro experiments.

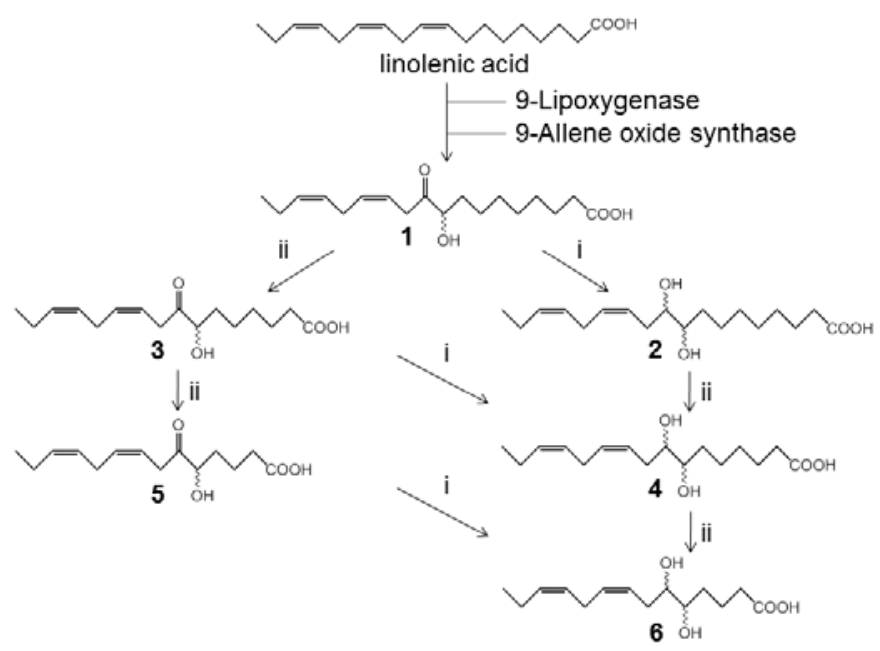

Fig. 1. Proposed metabolic transformations of 1 via $\alpha$-ketol reduction (i) and $\beta$-oxidation (ii). ${ }^{5}$

\section{Results and discussions}

\subsection{Stereo-selective synthesis and purification of enantiomeric diols derived from 1}

In order to elucidate the stereochemistry of the reduction at C10 in vivo and in vitro feeding experiments with $\mathbf{1}$, diastereomers of 2 were prepared from 1 by reduction with $\mathrm{NaBH}_{4}$ and their absolute configurations were determined by the NMR analyses. Initially, $(R)-\mathbf{1}$ and $(S)-\mathbf{1}$ were separated by chiral HPLC. The $(R)-\mathbf{1}$ and $(S)-\mathbf{1}$ were separately converted into the diols 2a-1, $\mathbf{2 a - 2}$ and $\mathbf{2 b - 1}, \mathbf{2 b}-\mathbf{2}$ respectively (Scheme 1). The C-10 enantiomers were purified by HPLC on ODS and chiral columns (Fig. S1). 


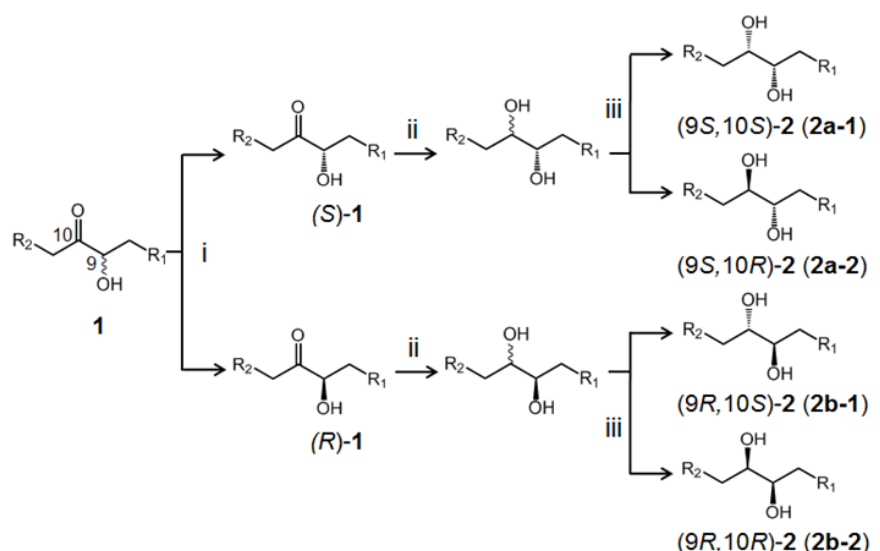

Scheme 1: Synthesis and purification of the four stereoisomers of 2. i) chiral phase HPLC separation

ii) $\mathrm{NaBH}_{4}$ /ethanol

iii) chiral HPLC separation.

The enantiomers could only be separated and assigned based on their retention times on the chiral column (Fig. 2). We determined configuration of $\mathbf{2} \mathbf{b}-\mathbf{2}$ by long range coupling constants and modified Mosher's method.

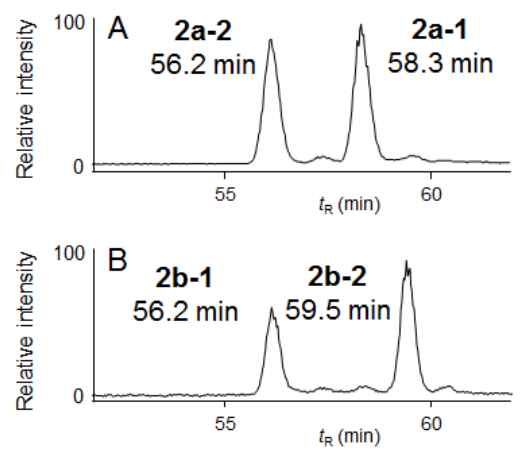

Fig. 2. LC-MS chromatograms $\left(m / z 311[\mathrm{M}-\mathrm{H}]^{-}\right)$of 2 diastereomers synthesized from $(S)-\mathbf{1}(\mathrm{A})$ and $(R)-\mathbf{1}(\mathrm{B})$ separeted on the chiral HPLC column.

\subsection{Determination of the absolute configurations by the measurement of long range coupling constants}

Recently, heteronuclear long range coupling constants have been utilized in stereo-chemical investigations of acyclic systems. $^{7,8}$ This method has a number of advantages in elucidating the absolute configurations of acyclic asymmetric carbons and is applicable for determining configurations of consecutive asymmetric carbons without chemical derivatizations These approaches rely upon the determination of coupling constants between protons and carbons separated by two or three chemical bonds. It is well established that ${ }^{3} J_{\mathrm{H}-\mathrm{H}}$ and ${ }^{3} J_{\mathrm{C}-\mathrm{H}}$ values depend on the dihedral angle between proton and carbon at the vicinal position and ${ }^{2} J_{\mathrm{C}-\mathrm{H}}$ depends on the dihedral angle between proton and oxygen atom at the vicinal position. As a result, $\mathbf{2 b - 1}$ and $\mathbf{2 b}-\mathbf{2}$ form six possible rotamers around $\mathrm{C}-9$ and $\mathrm{C}-10$ showing different coupling constant values (Fig. S2).

The analyses of the width of spectral line of $\mathrm{C}-11$ at the slice A and the coupling constant between $\mathrm{H}-9$ and C- $11{ }^{3} J_{\mathrm{H} 9-\mathrm{C} 11}$ which was determined to be less than $3 \mathrm{~Hz}$ suggested that the relationship between $\mathrm{H}-9$ and $\mathrm{C}-11$ is gauche. In the same manner, ${ }^{3} J_{\mathrm{H} 10-\mathrm{C} 8},{ }^{2} J_{\mathrm{H} 10-\mathrm{C} 9}$, and ${ }^{2} J_{\mathrm{H} 9-\mathrm{C} 10}$ were determined to be less than $3 \mathrm{~Hz}$ were designated as gauche conformation. Although we measured ${ }^{3} J_{\mathrm{H} 9-\mathrm{H} 10}$ by ${ }^{1} \mathrm{H}-\mathrm{NMR}$, it was not appropriate to elucidate the actual vicinal coupling constant because the chemical shifts of protons were not resolved. As shown in Fig. 3-A the signals of $\mathrm{H}-9$ and $\mathrm{H}-10$ were partially overlapping.

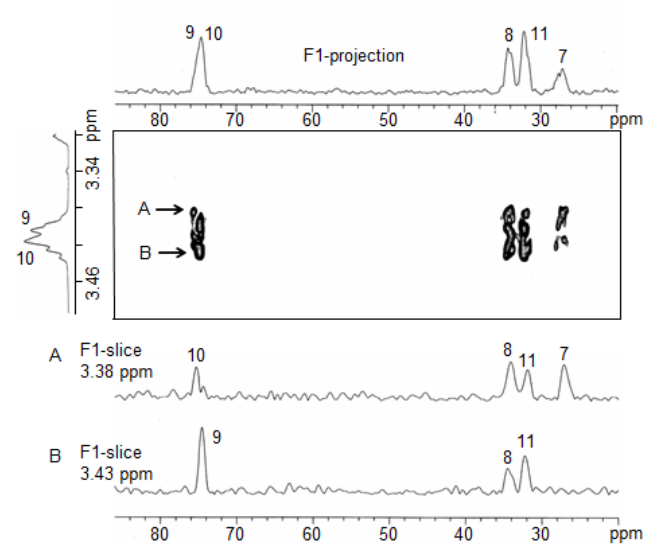

Fig. 3-A. J-resolved HSQC spectrum of C-9 and C-10 of $\mathbf{2 b - 2}$. A slice at $\delta 3.38(\mathrm{H}-9)$; B slice at $\delta 3.43(\mathrm{H}-10)$.

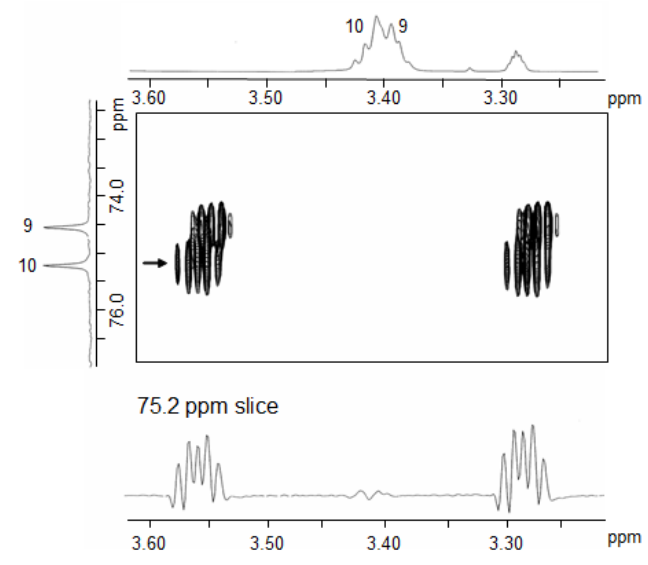

Fig. 3-B. $J$-resolved HSQC spectrum of C-9 and C-10 between satellite signals of $\mathrm{H}-9$ and $\mathrm{H}-10$ of $\mathbf{2 b - 2}$.

Therefore we measured the $J$-resolved HSQC spectrum at C-10 position $(\delta 75.2)$ showing cross peaks based on the satellite signals separated by ${ }^{1} J_{\mathrm{C} 10-\mathrm{H} 10}$ (Fig. 3-B). Based on these results, spectral data of $\mathrm{H}-10$ could be satisfactorily analyzed. The spectral pattern showed that ${ }^{3} J_{\mathrm{H} 9-\mathrm{H} 10}$ is $4 \mathrm{~Hz}$. In addition, the ${ }^{3} J_{\mathrm{H} 10-\mathrm{H} 11 \mathrm{a}}$ and ${ }^{3} J_{\mathrm{H} 10-\mathrm{H}-11 \mathrm{~b}}$ were measured by the decoupling experiments at $\mathrm{H}-11$ signals and were 5 and $7 \mathrm{~Hz}$, respectively. Although ${ }^{3} J_{\mathrm{H} 9-\mathrm{C} 10}$ with a value of $4 \mathrm{~Hz}$ was slightly higher than that for the gauche form, it indicated gauche conformation. Moreover, there were no divergent results for ${ }^{2,3} J_{\mathrm{C}-\mathrm{H}}$ coupling, and therefore $\mathrm{H}-9$ and $\mathrm{H}-10$ was designated to be gauche. Based on the ${ }^{2,3} J_{\mathrm{C}-\mathrm{H}},{ }^{3} J_{\mathrm{H}-\mathrm{H}}$ data, we successfully determined the stereochemistry at $\mathrm{C}-10$ position of $\mathbf{2 b}-\mathbf{2}$ to be $R$ configuration by measurement of long range coupling constants.

2.3. Determination of the absolute configurations by modified Mosher's method 
Modified Mosher's method is effective in determination of the absolute configurations of secondary alcohols. ${ }^{9}$ This method relies on the fact that the protons in diastereomeric mono- $\alpha$ methoxy- $\alpha$-(trifluoromethyl) phenylacetyl (MTPA) esters display different chemical shifts in their ${ }^{1} \mathrm{H}-\mathrm{NMR}$ spectra. Firstly, 2b-2 was converted to its methyl ester which was subsequently derivatized to its MTPA ester and purified by HPLC prior NMR analysis. The (S)-MTPA ester of $\mathbf{2 b}-\mathbf{2}$ was obtained similarly. The proton and carbon signals of $\mathbf{2 b}-\mathbf{2}$ were assigned on the bases of ${ }^{1} \mathrm{H}-{ }^{1} \mathrm{H}$ COSY and $\mathrm{HMBC}$ spectra. Alterations of chemical shifts were calculated based on the modified Mosher's method and higher frequency $(+\Delta \delta)$ shifted for C-11 to C-18 and lower frequency $(-\Delta \delta$ ) shifted for C-7, C-8, and C-3 (Fig. 4).

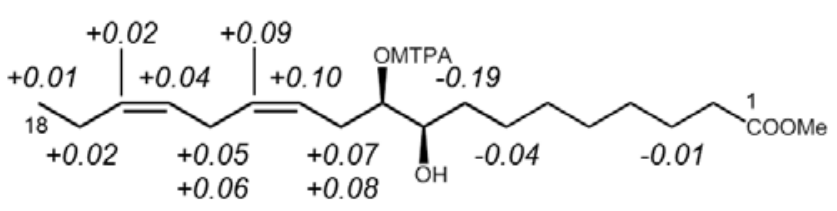

Fig. 4. Chemical shift differences $\Delta \delta(S-R)$ of MTPA esters derived from $\mathbf{2 b}-\mathbf{2}$.

Based on these results, the absolute configuration at C-10 of $\mathbf{2 b}$ 2 was determined to be $R$. Thus, we could unambiguously determine the absolute configuration at C-9 and C-10 of one of the diastereomers based on the long range coupling constants and the modified Mosher's method. Therefore, the absolute configuration at C-10 of the other diol isomer $\mathbf{2 b - 1}$ from $(R)-\mathbf{1}$ was assigned to be $S$. The results of the absolute configurations of $\mathbf{2 b} \mathbf{2} \mathbf{2}$ by Mosher's method were the same as the results obtained by the measurement of long range coupling constants and enabled us to study the stereochemistry of the reduction of $\mathbf{1}$ and its analogues in vivo and in vitro.

\subsection{Stereo-selective conversion of 1 into 2 in vivo}

In the in vivo system, exogenously-applied (R)-1 and (S)-1 were metabolized to their respective diols (Fig. 5). As a result, seedlings gave 2a-1 $(9 S, 10 S)$ mainly upon feeding with $(S)-\mathbf{1}$, likewise, $(R)-\mathbf{1}$ was converted mainly into $\mathbf{2 b - 1}(9 R, 10 S)$ (Fig. 6). These results indicate that $\alpha$-ketol reduction at C-10 of 1 predominantly yielded $10 S$ regardless of the C-9 configuration. In fact, the proportion of the conversion into $S$ configuration at C-10 was ca. $90 \%$ for both.

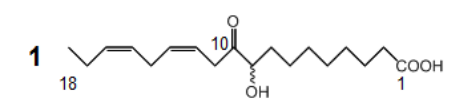

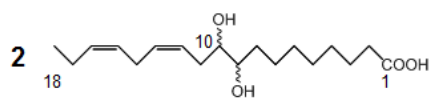

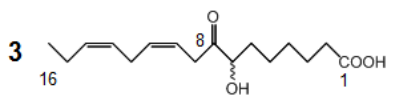

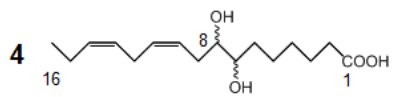

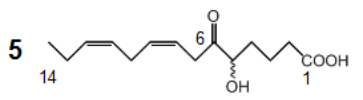

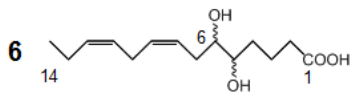

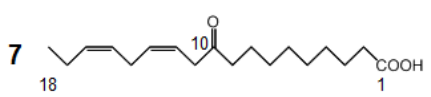

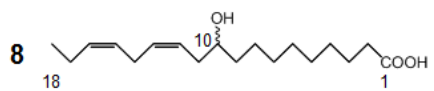

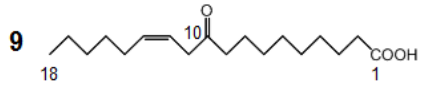

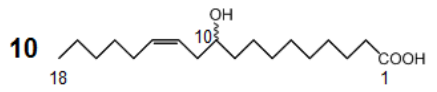

Fig. 5. Structures of keto-oxylipins (odd numbers) and related alcohols (even numbers) investigated in this study.

\subsection{Enantio-selective reduction of carbonyl groups of 1 and its analogues in vitro}

We extracted crude enzymes containing keto-reductases from seedlings of P.nil to confirm the enantio-selective conversion of 1 and its analogues. Various oxylipins, including 1 and other $\beta$ oxidative metabolites of $P$. nil have carbonyl moieties (unpublished). We investigated the in vitro enantio-selective reduction with keto oxylipins, $\mathbf{1}, \mathbf{3}, \mathbf{5}, 7$, and $\mathbf{9}$. The $R$ - and $S$ enantiomers of $\mathbf{1}, \mathbf{3}$, and $\mathbf{5}$ and ketones $\mathbf{7}$ and $\mathbf{9}$ were separately incubated with crude enzymes of the $P$. nil. The enantioselectivity of the keto-reduction was determined by comparison of the retention times of tolal ion traces of their corresponding alcohols based on the LC-MS analysis (Table S1). $S$ enantioselective reduction occurred with 1, 3, 7, and 9 (Table 1). The orientation of alcohol moiety did not affect the enantio-selectivity.

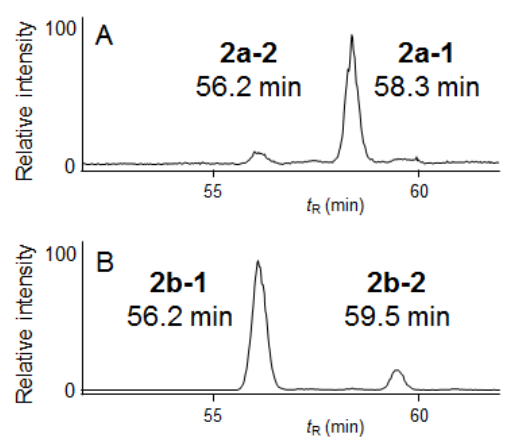

Fig. 6. LC-MS chromatograms $\left(\mathrm{m} / z 311[\mathrm{M}-\mathrm{H}]^{-}\right)$of 2 diastereomers extracted from P.nil administered with $(S)-\mathbf{1}(\mathrm{A})$ and $(R)-1$ (B) separated on the chiral HPLC column. 
Table 1. Stereo-selectivity of the keto-reduction of $\mathbf{1}$ and its analogues

\begin{tabular}{ccc}
\hline \multirow{2}{*}{ Substrate } & \multicolumn{2}{c}{ Selectivity $(\%)^{\mathrm{a}, \mathrm{b}}$} \\
\cline { 2 - 3 } & $S$ & $R$ \\
\hline$(R)-\mathbf{1}$ & 89 & 11 \\
$(S)-\mathbf{1}$ & 89 & 11 \\
$(R)-\mathbf{3}$ & 76 & 24 \\
$(S)-3$ & 86 & 14 \\
$(R)-5$ & 25 & 75 \\
$(S)-5$ & 72 & 28 \\
$\mathbf{7}$ & 19 & 81 \\
$\mathbf{9}$ & 17 & 83 \\
\hline
\end{tabular}

a All the products were characterized by ${ }^{1} \mathrm{H}-\mathrm{NMR}$ spectroscopy and mass spectroscopy and were in accordance to previously published data. ${ }^{10}$

b Selectivity was determined by co-chromatography with authentic reference substances (Table S1).

Although the opposite enantio-selectivity was observed for $(R)-5,(S)-5$ was reduced with $S$ enantio-selectivity. In planta huge numbers of reductases have been reported, ${ }^{11,12}$ these enzymes are classified into sub families which catalyze reactions enantio-selectively. The crude enzymes prepared for use in these experiments may contain several types of enzymes involved in the keto-reduction, despite that in the present study $S$ enantioselectivity was observed in vivo and in vitro experiments. Although the enantio-selectivity showed $R$ selectivity by feeding $\mathbf{7}$ and $\mathbf{9}$, but the face-selectivity was the same as for $\mathbf{1}$ and $\mathbf{3}$. In addition, neither orientation of $\alpha$-keto-hydroxyl groups nor presence of alcohol groups or double bonds affected the enantioselectivity of the in vitro reaction. We also investigated the turnover rates in vitro. $(R)-\mathbf{1}$ was approximately two fold easier converted into 2 than $(S)$-1. Similarly $R$ analogues were more easily reduced than their $S$ analogues (Fig. 7). Faster turnover rates were observed with longer aliphatic chains of the substrates in the keto-reduction. As there were no differences in the conformational energy (data not shown) between C-9 and C-10 of $\mathbf{2 b - 1}$ and $\mathbf{2 b}-\mathbf{2}$, orientation of 9-OH substantially influenced the enantio-selectivity of the keto-reduction.

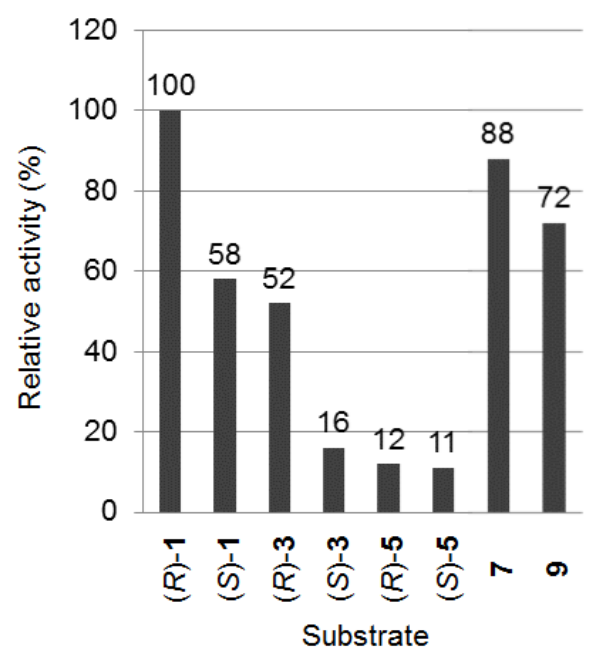

Fig. 7. Keto-reducase activities toward 1 and its analogues. The activities were expressed as reactivity (\%) relative to $(R)-\mathbf{1}$.

\section{Conclusion}

The previous study demonstrated that exogenously-applied $\mathbf{1}$ is mainly metabolized via reduction and $\beta$-oxidation. ${ }^{6}$ This study shows that $\mathbf{1}$ and all analogues except $(R)-\mathbf{5}$ are converted to their corresponding alcohols in same face-selective keto-reduction in vivo and in vitro. All the $R$-enantiomer of $\alpha$-ketols (1 and 3) were easily metabolized to their $S$ alcohols. Compounds lack in the 9-hydroxyl group (7 and 9) were metabolized with lower turnover rates. Compounds $\mathbf{3}$ and $\mathbf{5}$, in which the fatty acid chain length is shortened, were reduced with lower rates than $\mathbf{1}$. These results show the $R$-enantiomers of $\mathrm{C} 18 \alpha$-ketol oxylipin (1) are the most favorable substrates for the enantio-selective ketoreduction. In the plants, compounds that have physiological significance activities are controlled by biosynthetic enzymes and metabolic enzymes. Therefore $\mathbf{1}$ needs to be metabolized immediately in plants after flower-inducing activity. Our clarified results indicated presence of some important metabolic enzymes in $P$. nil, and these enzymes are suit for metabolizing 1.

\section{Experimental}

\subsection{General procedures}

${ }^{1} \mathrm{H},{ }^{13} \mathrm{C}$ NMR, and 2D NMR spectra were recorded on a JNM$\lambda 500 \alpha$ spectrometer and $\lambda 270 \alpha$ spectrometer (JEOL, Tokyo, Japan). Long range couplings for $J$-resolved HMBC-2 and $J$-resolved HSQC spectra were recorded with a resolution of $J_{\mathrm{C}-\mathrm{H}}=2.4 \mathrm{~Hz}$ with JEOL JNM- $\lambda 500 \mathrm{NMR}$ spectrometer. Highresolution mass spectra were obtained with a JMS-T100LC AccuTOF mass spectrometer (JEOL). Recycle HPLC was performed with a JASCO PU-9986 LC pump equipped with JASCO 875-UV detector (Tokyo, Japan). LC-MS analyses were carried out with a LC-10VP system equipped with LC-MS 2010A mass spectrometer (Shimadzu, Kyoto, Japan). HPLC separation was performed with a JASCO (Tokyo, Japan) LC system. Solvents for HPLC were purchased from Kanto Chemical (Tokyo, Japan). A two-solvent system was used to generate the mobile phase for HPLC: solvent A, aqueous $0.05 \%$ trifluoroacetic acid; solvent $\mathrm{B}$, acetonitrile.

\subsection{Plant materials}

P. nil cv. Violet (Marudane, Kyoto, Japan) was germinated as described previously. ${ }^{6}$ Seeds of $P$. nil were immersed in concentrated $\mathrm{H}_{2} \mathrm{SO}_{4}$ at $35{ }^{\circ} \mathrm{C}$ for 25 min and were subsequently washed in running water overnight. The seeds were placed on soil and incubated at $25{ }^{\circ} \mathrm{C}$ under continuous light (84 $\mu \mathrm{mol} / \mathrm{m}^{2} \mathrm{~s}^{1}$ ). Three day-old plants were transferred to Nakayama's liquid culture and incubated at $25^{\circ} \mathrm{C}$ under light $(84$ $\mu \mathrm{mol} / \mathrm{m}^{2} \mathrm{~s}^{1}$ ) for $5-6 \mathrm{~h}$ to synchronize the growth of the seedlings. Seeds were exposed to dark-period for $14 \mathrm{~h}$ to elevate enzymatic activity after the light period, a mandatory step as shown in the previous study. ${ }^{4}$

\subsection{Purification of $R$ and $S$ enantiomers of keto-alcohols 1,3 ,} and 5 and alcohols 8 and 10

Compound $1(R / S=3 / 1)$ was obtained from Shiseido as enantiomeric mixture. Further purification was carried out to isolate $(R)-\mathbf{1}$ and $(S)-\mathbf{1}$ by using a HPLC equipped with chiral column (CHIRALCELL OD-RH 4.6×150 mm, DAICEL, Japan). ${ }^{10}$ The recycle HPLC conditions were as follows: flow rate, 5.0 $\mathrm{mL} / \mathrm{min}$; mobile phase, $\mathrm{A}: \mathrm{H}_{2} \mathrm{O}(0.05 \%$ TFA), B: MeCN; solvent, isocratically $\mathrm{B} /(\mathrm{A}+\mathrm{B}) \quad 1: 1(\mathrm{v} / \mathrm{v})$; temperature, $4{ }^{\circ} \mathrm{C}$. Each enantiomer $(R)-1$ and $(S)-1$ fraction was evaporated, and the 
remaining aqueous layer was extracted with trichloromethane thrice. Thereafter, the organic layer was washed with anhydrous $\mathrm{NaCl}$ and dehydrated with anhydrous sodium sulfate prior to evaporation of the solvent to yield $(R)-\mathbf{1}^{10}(160 \mathrm{mg}$, ee $98 \%$; $\left.[\alpha]^{23}-13.8^{\circ}, c 0.63, \mathrm{CH}_{3} \mathrm{OH}\right)$ and $(S)-\mathbf{1}^{10}\left(50 \mathrm{mg}\right.$, ee $97 \% ;[\alpha]^{23}{ }_{\mathrm{D}}$ $+12.5^{\circ}$, c $\left.0.63, \mathrm{CH}_{3} \mathrm{OH}\right)$ as colorless amorphous solids from 1 $(400 \mathrm{mg})$. In the same manner enantiomers of 3 and 5 were isolated to give $(R)-3(0.9 \mathrm{mg}),(S)-3(1.5 \mathrm{mg})$ from $3(R / S=1 / 1$, $10.3 \mathrm{mg})$, and $(R)-\mathbf{5}(1.9 \mathrm{mg})$ and $(S)-5(2.4 \mathrm{mg})$ from $5(R / S=1 / 1$, $11.9 \mathrm{mg})$, respectively. The absolute configuration of the enantiomers were determined based on the optical rotation (described in 4.9.2).

In the same manner $(R)-8(21.2 \mathrm{mg}),(S)-8(19.4 \mathrm{mg})$ from 8 $(R / S=1 / 1,60.1 \mathrm{mg})$, and $(R)-\mathbf{1 0}(20.0 \mathrm{mg})$ and $(S)-\mathbf{1 0}(19.4 \mathrm{mg})$ from $10(R / S=1 / 1,61.3 \mathrm{mg})$ were obtained. The absolute configuration of the enantiomers were determined based on modified Mosher's method (described in Fig. S3) after methylation of each compound as described in 4.5.

\subsection{Conditions of the measurement of long range coupling constants}

${ }^{2,3} J_{\mathrm{C}-\mathrm{H}}$ of $\mathbf{2 a - 2}$ were detected by $J$-resolved HMBC-2 spectra (Fig. 3-B) with a scaling factor (n) of 25 and the digital resolution $J_{\mathrm{C}-\mathrm{H}}=2.4 \mathrm{~Hz}$; the slice of position A (at $\delta 3.38$ ) showing coupling constants between $\mathrm{H}-9$ and each carbon; the slice of $\mathrm{B}$ (at 83.43 ) showing coupling constants between $\mathrm{H}-10$ and each carbons. All conditions were identically to the established method by Furihata and Seto. ${ }^{8}$

\subsection{Derivatization by modified Mosher's method}

2a-2 ((9R,10R)-2, $13.6 \mathrm{mg}, 43.6 \mu \mathrm{mol})$ in methanol was treated with trimethylsilyl diazomethane $(200 \mu \mathrm{mol})$ to give 2a-2 $(9 R, 10 R)-2$ methyl ester $(14.0 \mathrm{mg}, 36.8 \mu \mathrm{mol})$. The methyl ester $(7.0 \mathrm{mg}, 21.5 \mu \mathrm{mol})$ in dichloromethane was treated with 1.5 equivalents of $(R)$-MTPA chloride in the presence of 4dimethylaminopyridine, and the mixture was stirred at room temperature for $12 \mathrm{~h}$. The mixture was purified by column chromatography on silica gel (hexane:ethyl acetate/4:1 (v/v)) and HPLC on ODS column $(\mathrm{B}: \mathrm{A} / 4: 1(\mathrm{v} / \mathrm{v}))$. The target compound 10-mono-MTPA ester $(1.4 \mathrm{mg}$, yield $17.0 \%)$ was obtained together with 9,10-di- $(2.0 \mathrm{mg}$, yield $17.0 \%)$ and 9-mono-MTPA ester $(2.9 \mathrm{mg}$, yield $35.4 \%)$. The 9-mono-(S)-MTPA (1.2 mg, yield $14.6 \%)$ was obtained together with 9,10 -di- $(1.5 \mathrm{mg}$, yield $13.0 \%)$ and 10-mono-MTPA (2.1 mg, yield 25,0\%) from $S$ MTPA under the same methods. The chirality at $\mathrm{C}-10$ position was determined based on the ${ }^{1} \mathrm{H}-\mathrm{NMR}$ spectra.

The MTPA esters of $(R)-8$ and (S)-8 methyl esters and those of $(R)$ - and (S)-10 methyl esters were prepared in an usual manner and purified by successive column chromatography and HPLC on ODS column as mentioned above. $(R)-8-(R)$-MTPA ester $(2.3$ $\mathrm{mg}$; yield $32 \%),(R)-8$ - $(S)$-MTPA ester $(6.0 \mathrm{mg}$; yield $84 \%),(R)$ 10-(R)-MTPA ester (36.1 mg; yield 87\%), $(R)-10-(S)$-MTPA ester (6.2 mg; yield $85 \%$ ) were obtained. The configuration was determined as described in 4.9.4 and 4.9.5

\subsection{In vivo experiments and LC-MS analyses of the metabolites of $(R)-1$ and $(S)-1$}

Three cotyledons $(0.3 \mathrm{~g}$ fresh weight each) of $P$. nil were immersed in a solution $(5 \mathrm{~mL})$ of $(R)-\mathbf{1}(320 \mu \mathrm{mol} / \mathrm{mL})$ or $(S)-\mathbf{1}$ $(320 \mu \mathrm{mol} / \mathrm{mL})$ under reduced pressure $(30 \mathrm{mmHg})$ for $1 \mathrm{~min}$. The seedlings were incubated at $25^{\circ} \mathrm{C}$ under continuous light $(84$ $\mu \mathrm{mol} / \mathrm{m}^{2} \mathrm{~s}^{1}$ ) for $10 \mathrm{~min}$. After incubation the seedlings were homogenized in liquid $\mathrm{N}_{2}$ and extracted with ethyl acetate five times by sonication for $1 \mathrm{~min}$. The extracts were combined and evaporated to dryness. The residue was dissolved in $20 \%(\mathrm{v} / \mathrm{v})$ acetonitrile. 1 and its metabolites 2a-1, 2a-2, 2b-1, and 2b-2 were eluted with $80 \%(\mathrm{v} / \mathrm{v})$ acetonitrile. The in vivo conversion of $(R)$ 1 and (S)-1 were examined by the LC-MS analyses. The conversion rates of $(R)-\mathbf{1}$ and $(S)-\mathbf{1}$ to the respective diols $\mathbf{2}$ were $6 \%$ and $3.2 \%$ of the amounts ( $\mathrm{ca} 0.8 \%$ ) of the administered in the seedlings. The LC-MS analysis was carried out in selected ion monitoring mode, the conditions were as follows: CAPCELLPAK AS-RH 4.6 $\times 150 \mathrm{~mm}$ (Shiseido, Japan); flow rate, $0.2 \mathrm{~mL} / \mathrm{min}$; gradient, keep $30 \%(\mathrm{v} / \mathrm{v}) \mathrm{B} /(\mathrm{A}+\mathrm{B}) 30 \mathrm{~min}$ and $30-$ $100 \%(\mathrm{v} / \mathrm{v}) \mathrm{B} /(\mathrm{A}+\mathrm{B})$ within $90 \mathrm{~min}$; column temperature, $30^{\circ} \mathrm{C}$. The MS conditions were set as follows: probe voltage $-3.5 \mathrm{kV}$ and gas flow rate $1.5 \mathrm{~mL} / \mathrm{min}$. Enantio excess (ee) and diasteromeric excess (de) were determined based on the peak area of each enantiomer or diastereomer. Enantiomeric compounds $\mathbf{2 a - 1}$ and $\mathbf{2} \mathbf{b}-\mathbf{2}$ gave different retention times of 58.3 min and $59.5 \mathrm{~min}$, respectively. $\mathbf{2 a - 2}$ and $\mathbf{2 b - 1}$ co-eluted at 56.2 min from the chiral column.

\subsection{Preparation of crude enzyme extract from P.nil}

Cotyledons of $P$. nil were kept in darkness for $16 \mathrm{~h}$ and incubated at $25^{\circ} \mathrm{C}$ under continuous light $\left(84 \mu \mathrm{mol} / \mathrm{m}^{2} \mathrm{~s}^{1}\right)$ for two weeks. The whole plant material $40 \mathrm{~g}$ was crushed with liquid nitrogen and homogenized in $400 \mathrm{~mL} 0.01 \mathrm{M}$ phosphate buffer (pH 8.0) containing $5 \mathrm{mM}$ dithiothreitol (DTT), $0.05 \% 3-((3-$ Cholamidopropyl)dimethylammonium)-1-propanesulfonate (CHAPS), 5\% glycerine), 30 g polyvinylpyrrolidone (PVPP) and $3 \mathrm{~mL}$ of $0.2 \mathrm{M}$ phenylmethylsulfonyl fluoride (PMSF) at $4{ }^{\circ} \mathrm{C}$. After extraction, the crude enzyme extract was centrifuged at $12,000 \mathrm{~g}$ for $20 \mathrm{~min}$ at $5{ }^{\circ} \mathrm{C}$ and $380 \mathrm{~mL}$ supernatant was obtained. The supernatant was filtered and $30 \%\left(\mathrm{NH}_{4}\right)_{2} \mathrm{SO}_{4}$ was deed up to concentration of $50 \%$. After incubation for $30 \mathrm{~min}$ on ice, the crude enzyme was centrifuged $12,000 \mathrm{~g}$ for $20 \mathrm{~min}$ at $5{ }^{\circ} \mathrm{C}$. The supernatant was filtered and $\left(\mathrm{NH}_{4}\right)_{2} \mathrm{SO}_{4}$ up to a concentration of $50 \%$ was added. Finally, another precipitation step to the final $\left(\mathrm{NH}_{4}\right)_{2} \mathrm{SO}_{4}$ concentration of $60 \%$ was carried out. The obtained protein pellet from the precipitation step from $50 \%$ to $60 \%\left(\mathrm{NH}_{4}\right)_{2} \mathrm{SO}_{4}$ was dissolved in $5 \mathrm{~mL} 0.1 \mathrm{M}$ phosphate buffer (pH 7.5, 5 mM DTT) and was used for the cell free assays.

\subsection{Stereo-selective conversion of 1 into 2 in vitro and its analogues LC-MS analysis}

Ten microlitter of the substrate $(10 \mathrm{mM})$ dissolved in DMSO, $100 \mu \mathrm{L}$ crude enzyme solution and $25 \mu \mathrm{L}$ NADPH (Oriental yeast) dissolved in $0.1 \mathrm{M}$ phosphate buffer ( $\mathrm{pH} 7.5,5 \mathrm{mM}$ DTT) were reacted for $2 \mathrm{~h}$ at $30^{\circ} \mathrm{C}$. After addition of $100 \mu \mathrm{L} 2 \mathrm{M} \mathrm{HCl}$ to stop the enzyme reaction, reactants were extracted with ethyl acetate $(1.5 \mathrm{~mL} \times 4)$. The extracted reaction products were analyzed by LC-MS. The LC-MS analysis was operated in selected ion monitoring mode. The chromatographic conditions were as follows: CAPCELLPAK AS-RH 4.6×150 mm (Shiseido, Japan); flow rate, $0.2 \mathrm{~mL} / \mathrm{min}$; gradient, keep $30 \%(\mathrm{v} / \mathrm{v}) \mathrm{B} /(\mathrm{A}+\mathrm{B})$ $30 \mathrm{~min}$ and $30-100 \%(\mathrm{v} / \mathrm{v}) \mathrm{B} /(\mathrm{A}+\mathrm{B})$ within $90 \mathrm{~min}$; column temperature, $30^{\circ} \mathrm{C}$. The MS was operated under the conditions described under 4.6. Enantio-selectivity of keto-reduction of 1, 3, 5, 7, and 9 were elucidated based on the LC-MS profiles by direct comparison with those of respective keto-ruduced compounds 2, 4, 6, 8, and 10. (Tables S1, S2).

\subsection{Synthesis of Compounds 2-10}

\subsubsection{Compound 2}


$(R)-1$ and $(S)-1^{10}(R)-1(20.0 \mathrm{mg}, 64.5 \mu \mathrm{mole})$ was dissolved in $1.0 \mathrm{~mL}$ ethanol and $\left.\mathrm{NaBH}_{4}(7.3 \mathrm{mg}, 194 \mu \mathrm{mol})\right)$ were stirred for $30 \mathrm{~min}$ at room temperature. After addition of $500 \mu \mathrm{L} 1 \mathrm{M} \mathrm{HCl}$ and $30 \mathrm{~mL} \mathrm{H} \mathrm{H}_{2} \mathrm{O}$, the reactants were washed with ethyl acetate 15 $\mathrm{mL}(\times 3)$. The combined ethyl acetate layers were washed with saturated $\mathrm{NaCl}$ solution and dehydrated by anhydrous $\mathrm{Na}_{2} \mathrm{SO}_{4}$ and concentrated under vacuum to give the diastereomers of 2 (20.0 mg, $46.0 \mu \mathrm{mol})$. The diasteromers were purified by preparative HPLC under the conditions as follows: CHIRALCELL OD-RH $20 \times 150 \mathrm{~mm}$ (DAICEL, Japan); flow rate, $5.0 \mathrm{~mL} / \mathrm{min}$; mobile phase, A: $\mathrm{H}_{2} \mathrm{O}(0.05 \% \mathrm{TFA}), \mathrm{B}: \mathrm{MeCN}$; solvent, isocratically $\mathrm{B} /(\mathrm{A}+\mathrm{B}) 1: 1(\mathrm{v} / \mathrm{v})$; column temperature, $15^{\circ} \mathrm{C} .(9 R, 10 R)-2(14.6 \mathrm{mg}$, yield $42 \%)$ and $(9 R, 10 S)-2(14.6 \mathrm{mg}$, yield $42 \%$ ) were obtained as colourless amorphous solid. In the similar manner, $(9 S, 10 R)-2$ (5.9 mg, yield 29\%) and (9S, 10S)-2 (8.2 mg, yield $42 \%$ ) were obtained from $(S)-\mathbf{1}$.

(9S,10S)-2 $[\alpha]^{26}{ }_{\mathrm{D}}-17.9^{\circ}\left(\mathrm{c} 0.56 \mathrm{CH}_{3} \mathrm{OH}\right) ; \mathrm{HR}-\mathrm{MS}\left(\mathrm{ESI}^{+}\right) \mathrm{m} / \mathrm{z}$ $335.2198[\mathrm{M}+\mathrm{Na}]^{+}$(calcd for $\left.\mathrm{C}_{18} \mathrm{H}_{32} \mathrm{NaO}_{4}, 335.2199\right) ;{ }^{13} \mathrm{C} \mathrm{NMR}$ $\left(125.0 \mathrm{MHz}, \mathrm{CD}_{3} \mathrm{OD}\right) \delta 14.6,21.5,26.1,26.6,27.0,30.2,30.4$, $30.7,32.1,34.1,35.1,74.6,75.2,127.3,128.3,130.9,132.7$, 177.8 .

$(9 R, 10 R)-2[\alpha]^{26}{ }_{\mathrm{D}}+14.6^{\circ}\left(\mathrm{c} 0.63 \mathrm{CH}_{3} \mathrm{OH}\right) ; \mathrm{HR}-\mathrm{MS}\left(\mathrm{ESI}^{+}\right) \mathrm{m} / \mathrm{z}$ $335.2200[\mathrm{M}+\mathrm{Na}]^{+}$(calcd for $\mathrm{C}_{18} \mathrm{H}_{32} \mathrm{NaO}_{4}, 335.2199$ ); ${ }^{13} \mathrm{C} \mathrm{NMR}$ $\left(125.0 \mathrm{MHz}, \mathrm{CD}_{3} \mathrm{OD}\right) \delta 14.6,21.5,26.6,27.0,27.8,30.5,30.6$, $30.7,32.1,34.2,39.3,74.6,75.2,127.3,128.3,130.9$, 132.7, 177.8 .

$(9 R, 10 S)-2[\alpha]^{26}{ }_{D}-0.7^{\circ}\left(c \quad 0.37 \quad \mathrm{CH}_{3} \mathrm{OH}\right) ; \mathrm{HR}-\mathrm{MS} \quad\left(\mathrm{ESI}^{+}\right) \mathrm{m} / \mathrm{z}$ $335.2200[\mathrm{M}+\mathrm{Na}]^{+}$(calcd for $\mathrm{C}_{18} \mathrm{H}_{32} \mathrm{NaO}_{4}, 335.2199$ );

${ }^{13} \mathrm{C}$ NMR (125.0 MHz, CD $\mathrm{OD}$ ) identical with (9S,10R)-2.

$(9 S, 10 R)-2[\alpha]^{26}+1.2^{\circ}\left(c \quad 0.39 \mathrm{CH}_{3} \mathrm{OH}\right) ; \mathrm{HR}-\mathrm{MS}\left(\mathrm{ESI}^{+}\right) \mathrm{m} / \mathrm{z}$ $335.2201[\mathrm{M}+\mathrm{Na}]^{+}$(calcd for $\mathrm{C}_{18} \mathrm{H}_{32} \mathrm{NaO}_{4}, 335.2199$ ); ${ }^{13} \mathrm{C} \mathrm{NMR}$ (125.0 MHz, $\left.\mathrm{CD}_{3} \mathrm{OD}\right)$ identical with $(9 R, 10 S)-2$.

10-mono-( $R$ )-MTPA ester of $(9 R, 10 R)-2$ methyl ester HR-MS $\left(\mathrm{ESI}^{+}\right.$) $\mathrm{m} / \mathrm{z} 565.2375[\mathrm{M}+\mathrm{Na}]^{+}$(calcd for $\mathrm{C}_{29} \mathrm{H}_{41} \mathrm{~F}_{3} \mathrm{NaO}_{6}$, 565.2753); ${ }^{1} \mathrm{H}-\mathrm{NMR}\left(500 \mathrm{MHz}, \mathrm{CDCl}_{3}\right): \delta 0.96(3 \mathrm{H}, \mathrm{t}, J=6.5 \mathrm{~Hz}$, 18-H), 1.25 1.35 (6H, m, 4-H, 5-H, 6-H), $1.29(2 \mathrm{H}, \mathrm{m}, 7-\mathrm{H})$, 1.44 (2H, m, H-8), $1.61(2 \mathrm{H}, \mathrm{m}, 3-\mathrm{H}), 2.04$ (2H, m, 17-H), 2.30 $(2 \mathrm{H}, \mathrm{t}, J=7.6 \mathrm{~Hz}, 2-\mathrm{H}), 2.46(1 \mathrm{H}, \mathrm{m}, 11 \mathrm{a}-\mathrm{H}), 2.49(1 \mathrm{H}, \mathrm{m}, 11 \mathrm{~b}-\mathrm{H})$, $2.72(1 \mathrm{H}, \mathrm{m}, 14 \mathrm{a}-\mathrm{H}), 2.76(1 \mathrm{H}, \mathrm{m}, 14 \mathrm{~b}-\mathrm{H}), 3.53$ (3H, s, MTPA$\mathrm{OMe}), 3.65(1 \mathrm{H}, \mathrm{m}, 9-\mathrm{H}), 3.67$ (3H, s, OMe), $5.01(1 \mathrm{H}, \mathrm{m}, 10-$ $\mathrm{H}), 5.23(1 \mathrm{H}, \mathrm{m}, 15-\mathrm{H}), 5.29(1 \mathrm{H}, \mathrm{m}, 12-\mathrm{H}), 5.38(1 \mathrm{H}, \mathrm{m}, 16-\mathrm{H})$, $5.44(1 \mathrm{H}, \mathrm{m}, 13-\mathrm{H}), 7.40(3 \mathrm{H}, \mathrm{m}, \mathrm{bz}), 7.54(2 \mathrm{H}, \mathrm{m}, \mathrm{bz})$.

10-mono-(S)-MTPA ester of $(9 R, 10 R)$-2 methyl ester HR-MS (ESI ${ }^{+}$) $\mathrm{m} / \mathrm{z} 565.2390[\mathrm{M}+\mathrm{Na}]^{+}$(calcd for $\mathrm{C}_{29} \mathrm{H}_{41} \mathrm{~F}_{3} \mathrm{NaO}_{6}$, 565.2753); ${ }^{1} \mathrm{H}-\mathrm{NMR}\left(500 \mathrm{MHz}, \mathrm{CDCl}_{3}\right): \delta 0.97(3 \mathrm{H}, \mathrm{dd}, J=7.6$ $\mathrm{Hz}, 18-\mathrm{H}), 1.25$ (2H, m, 8-H), 1.20 1.35 (6-H, m, 4-H , 5-H , 6$\mathrm{H}), 1.62(2 \mathrm{H}, \mathrm{m}, 3-\mathrm{H}), 2.06(2 \mathrm{H}, \mathrm{m}, 17-\mathrm{H}), 2.30(2-\mathrm{H}, \mathrm{t}, J=6.3 \mathrm{~Hz}$, 2-H), 2.54(1H, m,11a-H), $2.56(1 \mathrm{H}, \mathrm{m}, 11 \mathrm{~b}-\mathrm{H}), 2.78(1 \mathrm{H}, \mathrm{m}, 14 \mathrm{a}-$ H), 2.81 (1H, m,14b-H),3.53 (3H, s, MTPA-OMe), $3.62(1 \mathrm{H}, \mathrm{m}$, 9-H), 3.67 (3H, s, OMe), $5.03(1 \mathrm{H}, \mathrm{dt}, J=6.3,4.0 \mathrm{~Hz}, 10-\mathrm{H}), 5.27$ $(1 \mathrm{H}, \mathrm{m}, 15-\mathrm{H}), 5.39(1 \mathrm{H}, \mathrm{m}, 12-\mathrm{H}), 5.40(1 \mathrm{H}, \mathrm{m}, 16-\mathrm{H}), 5.53(1 \mathrm{H}$, m, 13-H), 7.40 (3H, m, bz), 7.54 (2H, m, bz).

\subsubsection{Compounds 3 and 5}

Compounds $\mathbf{3}$ and $\mathbf{5}$ were obtained as described in our previous study and comfirmed the structures based on the HR-MS, ${ }^{1} \mathrm{H}$ - and ${ }^{13} \mathrm{C}-\mathrm{NMR} .{ }^{10}$ Enantiomers of $\mathbf{3}$ and $\mathbf{5}$ were isolated by chiral HPLC as described in 4.3 and the configurations were determined based on the optical rotation measurement. $[\alpha]^{26}{ }_{\mathrm{D}}+8.4^{\circ}\left(e e\right.$ 96\%; c $\left.0.80, \mathrm{CH}_{3} \mathrm{OH}\right)$ for $(S)-3 ;[\alpha]^{26}{ }_{\mathrm{D}}-6.7^{\circ}(e e$ $\left.94 \% ; c 0.60, \mathrm{CH}_{3} \mathrm{OH}\right)$ for $(R)-3 ;[\alpha]^{26}{ }_{\mathrm{D}}+1.5^{\circ}$ (ee $96 \%$; c 0.79 , $\left.\mathrm{CH}_{3} \mathrm{OH}\right)$ for $(S)-5$; $[\alpha]^{26}{ }_{\mathrm{D}}-1.5^{\circ}\left(e e 92 \% ; c 0.62, \mathrm{CH}_{3} \mathrm{OH}\right)$ for $(R)-$ 5.

\subsubsection{Compounds 4 and 6}

$(9 R, 10 R)-,(9 R, 10 S)-,(9 S, 10 R)-,(9 S, 10 S)-2$ (100 $\mu$ g each) was treated with $\beta$-oxidation enzyme (Asai Kasei, Shizuoka, Japan) ${ }^{13}$, comprising with acyl-CoA synthetase (ACS) , acyl-CoA oxidase (ACOD), 2-enoylacyl-CoA hydratase, 3-hydroxyacyl-CoA dehydrogenase, and 3-ketoacyl-CoA thiolase multienzyme (HDT). After the incubation for $12 \mathrm{hr}$ at $30{ }^{\circ} \mathrm{C}$, the reaction mixture was extracted with ethyl acetate and the organic layer was subjected to HPLC analysis on an analytical chiral column under the conditions described in Fig. S1. As the conversion rate of each diastereomer 2 was $\mathrm{ca}$. $10 \%$, only trace amount of the corresponding diastereomers (7R,8R)-, 7R,8S)-, (7S,8R)-, (7S,8S)-4 and $(5 R, 6 R)-, 5 R, 6 S)-$, $(5 S, 6 R)-, \quad(5 S, 6 S)-6$ were produced from $(9 R, 10 R)-,(9 R, 10 S)-,(9 S, 10 R)-,(9 S, 10 S)-2$, respectively without any epimerization. (Table S1) Enantioselectivity of in vitro conversion was determined by directly comparing with these compounds.

\subsubsection{Compound 8}

Compound 7 (22.6 mg, $76.8 \mu \mathrm{mol})$ dissolved in $3.0 \mathrm{~mL}$ ethanol and $\mathrm{NaBH}_{4}(10.0 \mathrm{mg}, 265 \mu \mathrm{mol})$ were stirred for $30 \mathrm{~min}$ at room temperature. After addition of $500 \mu \mathrm{L} 1 \mathrm{M} \mathrm{HCl}$ and $30 \mathrm{~mL} \mathrm{H}_{2} \mathrm{O}$, the reactants were washed with ethyl acetate $15 \mathrm{~mL}(\times 3)$. The combined ethyl acetate layers were washed with saturated $\mathrm{NaCl}$ solution and dehydrated by anhydrous $\mathrm{Na}_{2} \mathrm{SO}_{4}$ and concentrated under vacuum to give the respective enantiomer of $8(20.0 \mathrm{mg}$, $68.0 \mu \mathrm{mol}) .{ }^{1} \mathrm{H}-\mathrm{NMR}\left(270 \mathrm{MHz}, \mathrm{CDCl}_{3}\right) \delta 0.97(3 \mathrm{H}, \mathrm{t}, 7.4 \mathrm{~Hz}$, $18-\mathrm{H}), 1.26-1.40(10 \mathrm{H}, \mathrm{m}, 4 \sim 8-\mathrm{H}), 1.43-1.50(2 \mathrm{H}, \mathrm{m}, 9-\mathrm{H}), 1.63$ (2H, m, 3-H), $2.07(2 \mathrm{H}, \mathrm{m}, 17-\mathrm{H}), 2.27$ (2H, t-like, J=6.6 Hz, 11$\mathrm{H}), 2.35(2 \mathrm{H}, \mathrm{t}, J=7.6 \mathrm{~Hz}, 2-\mathrm{H}), 2.81(2 \mathrm{H}, \mathrm{m}, 14-\mathrm{H}), 3.69(1 \mathrm{H}, \mathrm{m}$, $10-\mathrm{H}), 5.25-5.67\left(4 \mathrm{H}, \mathrm{m}, 12,13,15\right.$ and 16-H). ${ }^{13} \mathrm{C}-\mathrm{NMR}(67.5$ $\left.\mathrm{MHz}, \mathrm{CD}_{3} \mathrm{OD}\right) \delta 14.2,20.6,24.6,25.5,29.0,29.1,29.3,29.4$, $34.0,35.0,36.5,72.1,125.0,126.7,131.8,132.3,180.1$. HRMS $\left(\mathrm{ESI}^{+}\right.$) $\mathrm{m} / \mathrm{z} 319.2243[\mathrm{M}+\mathrm{Na}]^{+}$(calcd for $\mathrm{C}_{18} \mathrm{H}_{32} \mathrm{NaO}_{3}, 319.2249$ ). Absolute configurations were elucidated based on the modified Mosher's method. The LC-MS analysis on a chiral HPLC was described in $\mathbf{4 . 8}$.

(S)-8 ee 96\%; $[\alpha]^{26}{ }_{\mathrm{D}}-5.2^{\circ}$ (c 1.29, $\left.\mathrm{CH}_{3} \mathrm{OH}\right) ;(R)-8$ ee $94 \%$; $[\alpha]^{26}+6.2^{\circ}\left(c 1.41, \mathrm{CH}_{3} \mathrm{OH}\right)$

Methyl esters of $(R)-\mathbf{8}$ and (S)-8 were prepared in the same manner as describe in $\mathbf{4 . 5}$.

\section{(S)-8-(R)-MTPA ester}

${ }^{1} \mathrm{H}-\mathrm{NMR}\left(500 \mathrm{MHz}, \mathrm{CDCl}_{3}\right): \delta 0.96(3 \mathrm{H}, \mathrm{t}, J=7.6 \mathrm{~Hz}, 18-\mathrm{H})$, 1.15-1.32 (8H, m, 4-7H), $1.18(2 \mathrm{H}, \mathrm{m}, \mathrm{H}-8), 1.56(2 \mathrm{H}, \mathrm{m}, 9-\mathrm{H})$, $1.59(2 \mathrm{H}, \mathrm{m}, 3-\mathrm{H}), 2.05(2 \mathrm{H}, \mathrm{m}, 17-\mathrm{H}), 2.30(2 \mathrm{H}, \mathrm{t}, J=7.6 \mathrm{~Hz}, 2-$ H), $2.38(1 \mathrm{H}, \mathrm{m}, 11 \mathrm{a}-\mathrm{H}), 2.48(1 \mathrm{H}, \mathrm{m}, 11 \mathrm{~b}-\mathrm{H}), 2.76(2 \mathrm{H}, \mathrm{m}, 14-$ $\mathrm{H}), 3.55$ (3H, s, MTPA-OMe), 3.67 (3H, s, -OMe), $5.12(1 \mathrm{H}, \mathrm{m}$, $10-\mathrm{H}), 5.26(1 \mathrm{H}, \mathrm{m}, \mathrm{H}-15), 5.38(2 \mathrm{H}, \mathrm{m}, 12$ and $16-\mathrm{H}), 5.50(1 \mathrm{H}$, m, H-13), 7.39 (3H, m, bz-H), $7.54(2 \mathrm{H}, \mathrm{m}, \mathrm{bz}-\mathrm{H}) ;{ }^{13} \mathrm{C}-\mathrm{NMR}$ $\left(125 \mathrm{MHz}, \mathrm{CDCl}_{3}\right) \delta 14.2,20.6,24.9 \times 2,25.7,29.1 \times 2,29.2 \times 2$, 29.7, 30.3, 31.8, 33.3, 34.1, 51.4, 55.5, 77.0, 124.0, 126.5, 127.4, $128.3,129.5,131.5,132.3,132.5,166.3,174.3$; HRMS $\left(\mathrm{ESI}^{+}\right)$ $\mathrm{m} / \mathrm{z}$ 549.2798 [M+Na] ${ }^{+}$(calcd for $\mathrm{C}_{29} \mathrm{H}_{41} \mathrm{~F}_{3} \mathrm{NaO}_{5}, 549.2804$ ).

\section{$(R)-8(S)$-MTPA ester}

${ }^{1} \mathrm{H}-\mathrm{NMR}\left(500 \mathrm{MHz}, \mathrm{CDCl}_{3}\right) \delta 0.96(3 \mathrm{H}, \mathrm{t}, J=7.6 \mathrm{~Hz}, 18-\mathrm{H}), 1.23-$ $1.33(8 \mathrm{H}, \mathrm{m}, 4-7 \mathrm{H}), 1.30(2 \mathrm{H}, \mathrm{m}, \mathrm{H}-8), 1.61(2 \mathrm{H}, \mathrm{m}, 3-\mathrm{H}), 1.63$ (2H, m, 9-H), $2.04(2 \mathrm{H}, \mathrm{m}, 17-\mathrm{H}), 2.30(2 \mathrm{H}, \mathrm{t}, J=7.6 \mathrm{~Hz}, 2-\mathrm{H})$, 
$2.33(1 \mathrm{H}, \mathrm{m}, 11 \mathrm{a}-\mathrm{H}), 2.39(1 \mathrm{H}, \mathrm{m}, 11 \mathrm{~b}-\mathrm{H}), 2.72(2 \mathrm{H}, \mathrm{m}, 14-\mathrm{H})$, $3.54(3 \mathrm{H}, \mathrm{s}$, MTPA-OMe $), 3.69(3 \mathrm{H}, \mathrm{s},-\mathrm{OMe}), 5.10(1 \mathrm{H}, \mathrm{m}, 10-$ $\mathrm{H}), 5.23(1 \mathrm{H}, \mathrm{m}, \mathrm{H}-15), 5.25(1 \mathrm{H}, \mathrm{m}, 12-\mathrm{H}), 5.38(2 \mathrm{H}, \mathrm{m}, 16-\mathrm{H})$, $5.42(1 \mathrm{H}, \mathrm{m}, \mathrm{H}-13), 7.39(3 \mathrm{H}, \mathrm{m}, \mathrm{bz}-\mathrm{H}), 7.54(2 \mathrm{H}, \mathrm{m}, \mathrm{bz}-\mathrm{H})$; ${ }^{13} \mathrm{C}-\mathrm{NMR}\left(125 \mathrm{MHz}, \mathrm{CDCl}_{3}\right) \delta 14.2,20.6,25.0 \times 2,25.6,29.1 \times 2$, $29.3 \times 2,29.7,30.3,31.5,33.4,34.1,51.4,55.5,77.0,123.7$, 126.6, 127.4, 128.3, 129.5, 131.4, 132.2, 132.5, 166.3, 174.3;

HRMS $\left(\mathrm{ESI}^{+}\right.$) $\mathrm{m} / \mathrm{z} 549.2799[\mathrm{M}+\mathrm{Na}]^{+}$(calcd for $\mathrm{C}_{29} \mathrm{H}_{41} \quad \mathrm{~F}_{3} \mathrm{NaO}_{5}$, 549.2804).

\subsubsection{Compound 10}

An enantiomeric mixture of $\mathbf{1 0}$ was obtained from $\mathbf{9}$ (19.9 mg, $67.1 \mu \mathrm{mol})$ under the conditions given in 4.9.3.

Compound $10(21.0 \mathrm{mg}, 70.5 \mu \mathrm{mol})$ : ${ }^{1} \mathrm{H}-\mathrm{NMR}(270 \mathrm{MHz}$, $\left.\mathrm{CDCl}_{3}\right) \delta 0.86(3 \mathrm{H}, \mathrm{t}, J=7.0 \mathrm{~Hz}, 18-\mathrm{H}), 1.31-1.50(18 \mathrm{H}, \mathrm{m}, 4-9-\mathrm{H}$ and 15-17-H), $1.63(2 \mathrm{H}, \mathrm{m}, 3-\mathrm{H}), 2.04(2 \mathrm{H}, \mathrm{m}, 17-\mathrm{H}), 2.21(2 \mathrm{H}$, t-like, $J=6.5 \mathrm{~Hz}, 11-\mathrm{H}), 2.34(2 \mathrm{H}, \mathrm{t}, J=7.6 \mathrm{~Hz}, 2-\mathrm{H}), 3.64(1 \mathrm{H}, \mathrm{m}$, $10-\mathrm{H}), 5.35-5.42(1 \mathrm{H}, \mathrm{m}, 12-\mathrm{H}), 5.52-5.62(1 \mathrm{H}, \mathrm{m}, 13-\mathrm{H})$; HRMS $\left(\mathrm{ESI}^{+}\right.$) $\mathrm{m} / \mathrm{z} 321.2404[\mathrm{M}+\mathrm{Na}]^{+}$(calcd for $\mathrm{C}_{18} \mathrm{H}_{34} \mathrm{NaO}_{3}$, 321.2406).

(R)-10 ee 98\%; $[\alpha]^{26}{ }_{\mathrm{D}}+12.3^{\circ}$ (c 1.33, $\left.\mathrm{CH}_{3} \mathrm{OH}\right)$; (S)-10 ee 98\%; $[\alpha]^{26}-11.5^{\circ}\left(c 1.29, \mathrm{CH}_{3} \mathrm{OH}\right)$.

\section{Methyl ester of $\mathbf{1 0}$}

${ }^{1} \mathrm{H}$ NMR $\left(270 \mathrm{MHz}, \mathrm{CDCl}_{3}\right) \delta 0.88(3 \mathrm{H}, \mathrm{t}, J=6.6 \mathrm{~Hz}), 1.31-$ 1.52,(18H, m), $1.63(2 \mathrm{H}, \mathrm{m}), 2.06(2 \mathrm{H}, \mathrm{m}), 2.21(2 \mathrm{H}, \mathrm{t}, J=6.6 \mathrm{~Hz})$, $2.30(2 \mathrm{H}, \mathrm{t}, J=7.6 \mathrm{~Hz}), 3.61(1 \mathrm{H}, \mathrm{m}), 3.67(3 \mathrm{H}, \mathrm{s}), 5.40(1 \mathrm{H}, \mathrm{m})$, $5.57(1 \mathrm{H}, \mathrm{m}) ;{ }^{13} \mathrm{C}$ NMR $\left(67.5 \mathrm{MHz}, \mathrm{CDCl}_{3}\right) \delta 14.0,22.5,24.9$, $25.7,27.4,29.1,29.2,29.3,29.4,29.6,31.5,34.1,35.4,36.8$, 51.4, 71.5, 125.1, 133.6, 174.3; HRMS $\left(\mathrm{ESI}^{+}\right) \mathrm{m} / \mathrm{z} 335.2545$ $[\mathrm{M}+\mathrm{Na}]^{+}$(calcd for $\mathrm{C}_{19} \mathrm{H}_{36} \mathrm{NaO}_{3}, 335.2562$ ).

$(R)-10-(R)-M T P A$ ester

${ }^{1} \mathrm{H}-\mathrm{NMR}\left(500 \mathrm{MHz}, \mathrm{CDCl}_{3}\right) \delta 0.88(3 \mathrm{H}, \mathrm{t}, J=7.0 \mathrm{~Hz}, 18-\mathrm{H}), 1.13-$ $1.37(10 \mathrm{H}, \mathrm{m}, 4-7,15-\mathrm{H}), 1.17(2 \mathrm{H}, \mathrm{m}, 8-\mathrm{H}), 1.25(2 \mathrm{H}, \mathrm{m}, 16-\mathrm{H})$, $1.28(2 \mathrm{H}, \mathrm{m}, 17-\mathrm{H}), 1.57(2 \mathrm{H}, \mathrm{m}, 9-\mathrm{H}), 1.59(2 \mathrm{H}, \mathrm{m}, 3-\mathrm{H}), 2.01$ $(2 \mathrm{H}, \mathrm{m}, 14-\mathrm{H}), 2.29(2 \mathrm{H}, \mathrm{t}, J=7.3 \mathrm{~Hz}, 2-\mathrm{H}), 2.36(1 \mathrm{H}, \mathrm{m}, 11 \mathrm{a}-\mathrm{H})$, $2.44(1 \mathrm{H}, \mathrm{m}, 11 \mathrm{~b}-\mathrm{H}), 3.54(3 \mathrm{H}, \mathrm{s}, \mathrm{MTPA}-\mathrm{OMe}), 3.67(3 \mathrm{H}, \mathrm{s},-$ OMe $), 5.11(1 \mathrm{H}, \mathrm{m}, 10-\mathrm{H}), 5.33(1 \mathrm{H}, \mathrm{m}, 12-\mathrm{H}), 5.52(1 \mathrm{H}, \mathrm{m}, 13-$ $\mathrm{H}), 7.40(3 \mathrm{H}, \mathrm{m}, \mathrm{bz}), 7.54(2 \mathrm{H}, \mathrm{m}, \mathrm{bz}) ;{ }^{13} \mathrm{C}-\mathrm{NMR}(125 \mathrm{MHz}$, $\left.\mathrm{CDCl}_{3}\right) \delta 14.0,22.5,24.9,24.9,29.1-29.2,31.5,31.7,33.3,34.1$, 51.5, 55.7, 77.2, 123.3, 133.3, 174.3; HRMS $\left(\mathrm{ESI}^{+}\right) \mathrm{m} / \mathrm{z} 551.2964$ $[\mathrm{M}+\mathrm{Na}]^{+}$(calcd for $\mathrm{C}_{29} \mathrm{H}_{43} \mathrm{~F}_{3} \mathrm{NaO}_{5}, 551.2960$ ).

(R)-10-(S)-MTPA ester

${ }^{1} \mathrm{H}-\mathrm{NMR}\left(500 \mathrm{MHz}, \mathrm{CDCl}_{3}\right) \delta 0.88(3 \mathrm{H}, \mathrm{t}, J=7.0 \mathrm{~Hz}, 18-\mathrm{H}), 1.13-$ $1.32(10 \mathrm{H}, \mathrm{m}, 4-7,15-\mathrm{H}), 1.24(2 \mathrm{H}, \mathrm{m}, 16-\mathrm{H}), 1.28(2 \mathrm{H}, \mathrm{m}, 17-$ $\mathrm{H}), 1.30(2 \mathrm{H}, \mathrm{m}, 8-\mathrm{H}), 1.61(2 \mathrm{H}, \mathrm{m}, 3-\mathrm{H}), 1.63(2 \mathrm{H}, \mathrm{m}, 9-\mathrm{H})$, $1.95(2 \mathrm{H}, \mathrm{m}, 14-\mathrm{H}), 2.30(2 \mathrm{H}, \mathrm{t}, J=7.3 \mathrm{~Hz}, 2-\mathrm{H}), 2.31(1 \mathrm{H}, \mathrm{m}$, $11 \mathrm{a}-\mathrm{H}), 2.35(1 \mathrm{H}, \mathrm{m}, 11 \mathrm{~b}-\mathrm{H}), 3.54(3 \mathrm{H}, \mathrm{s}$, MTPA-OMe $), 3.67$ $(3 \mathrm{H}, \mathrm{s},-\mathrm{OMe}), 5.09(1 \mathrm{H}, \mathrm{m}, 10-\mathrm{H}), 5.22(1 \mathrm{H}, \mathrm{m}, 12-\mathrm{H}), 5.43(1 \mathrm{H}$, $\mathrm{m}, 13-\mathrm{H}), 7.40(3 \mathrm{H}, \mathrm{m}, \mathrm{bz}), 7.54(2 \mathrm{H}, \mathrm{m}, \mathrm{bz}) ;{ }^{13} \mathrm{C}-\mathrm{NMR}(125$ $\left.\mathrm{MHz}, \mathrm{CDCl}_{3}\right) \delta 14.0,22.5,24.9,25.3,29.1-29.3 \times 4,31.5 \times 2$, 33.3, 34.1, 51.4, 55.7, 77.2, 123.3, 133.3, 174.3; HRMS $\left(\mathrm{ESI}^{+}\right)$ $\mathrm{m} / \mathrm{z} 551.2963[\mathrm{M}+\mathrm{Na}]^{+}$(calcd for $\mathrm{C}_{29} \mathrm{H}_{43} \mathrm{~F}_{3} \mathrm{NaO}_{5}, 551.2960$ ).

\section{Acknowledgments}

A part of this work was supported by a Grant in Aid for N.W. from the Research and Development Program for New Bioindustry Initiatives. We are grateful to Shiseido Co. Ltd., Japan for the gift of $\mathbf{1}$.

\section{References and notes}

1. Yokoyama, M.; Yamaguchi, S.; Inomata, S.; Komatsu, K.; Yoshida, S.; Iida, T.; Yokokawa, Y.; Yamaguchi, M.; Kaihara, S. Plant Cell Physiol. 2000, 41, 110-113.

2. Yokoyama, M.; Yamaguchi, S.; Suzuki, M.; Tanaka, O.; Kobayashi, K.; Yanaki1, T.; Watanabe, N. J. Plant Biotech. 2008, 25, 547-551.

3. Suzuki, M.; Yamaguchi, S.; Iida, T.; Hashimoto, I.; Teranishi, H.; Mizoguchi, M.; Yano, F.; Todoroki, Y.; Watanabe, N.; Yokoyama, M. Plant Cell Physiol. 2003, 44, 35-43.

4. Yokoyama, M.; Yamaguchi, S.; Iida, T.; Suda, A.; Saeda, T.; Miwa, T.; Ujihara, K.; Nishio, J. Plant Biotech. 2005, 22, 201-205.

5. Kai, K.; Akaike, R.; Iida, K.; Yokoyama, M.; Watanabe, N. Phytochemistry 2010, 71, 1168-1173.

6. Kai, K.; Yano, F.; Suzuki, F.; Kitagawa, H.; Suzuki, M.; Yokoyama, M.; Watanabe, N. Tetrahedron 2007, 63, 1063010636.

7. Matsumori, N.; Nonomura, T.; Sasaki, M.; Murata, M.; Tachibana, K.; Satake, M.; Yasumoto, T. Tetrahedron Lett. 1996, 37, 12691272 .

8. Furihata, K.; Seto, H. Tetrahedron Lett. 1999, 40, 6271-6275.

9. Ohtani, I.; Kusumi, T.; Kashman, Y.; Kakisawa, H. J. Am. Chem. Soc. 1991, 113, 4092-4096.

10. Kai, K.; Takeuchi, J.; Kataoka, T.; Yokoyama, M.; Watanabe, N. Tetrahedron 2008, 64, 6760-6769.

11. Persson, B.; Kallberg, Y.; Oppermann, U.; Jornvall, H. Chem. Biol. Interact. 2003, 143-144, 271-278.

12. Jez, J.M.; Bennett, M.J.; Schlegel, B.P.; Lewis, M.; Penning, T.M. Biochem. J. 1997, 325, 625-636.

13. Imamura, S.; Ueda, U.; Mizugaki, M.; Kawaguchi, A. ,J. Biochem., 1990, 107, 184-189. 

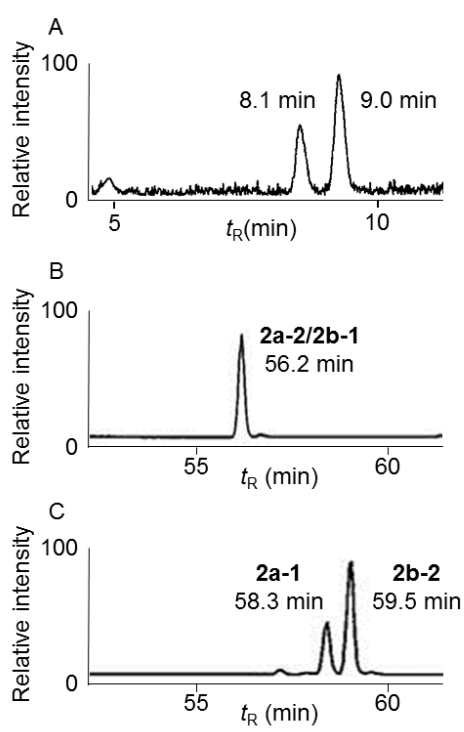

Supplementary Fig. 1. LC-MS analysis of the four diastereomeric isomers of $\mathbf{2}$ after $\mathrm{NaBH}_{4}$-reduction of $\mathbf{1}$ $(R / S=3 / 1)$. The products were traced at $m / z 311[\mathrm{M}-\mathrm{H}]$. The mixtures of $\mathbf{2 a - 1 , 2 a - 2}$ and $\mathbf{2 b}-\mathbf{1}, \mathbf{2} \mathbf{b}-\mathbf{2}$ were separated into their respective enantiomers on the ODS column. $\mathbf{2 a - 2}$ and $\mathbf{2 b - 1}$ showed identical retention times on the ODS column and the chiral column, indicating that these isomers are enantiomeric. $\mathbf{2 a - 1}$ and $\mathbf{2 b}-\mathbf{2}$ could not be distinguished by comparing chromatographic characteristic on ODS columns, on the other hand, separated on the chiral column.

(A) Separation of the four diastereomers of $\mathbf{2}$ on the ODS column. Each of enantiomeric mixture was eluted at $\mathrm{t}_{\mathrm{R}}=8.1 \mathrm{~min}$ and $\mathrm{t}_{\mathrm{R}}=9.0 \mathrm{~min}$.

(B) Analysis of peak with $t_{R}=8.1$ min on the chiral column. The two enantiomers $2 a-2$ and $2 b-1$ were co-eluted at $\mathrm{t}_{\mathrm{R}}=56.2 \mathrm{~min}$.

(C) Analysis of compounnds detected at $\mathrm{t}_{\mathrm{R}} 9.0$ on the chiral column traced at $m / z 311[\mathrm{M}-\mathrm{H}]^{-}$. 


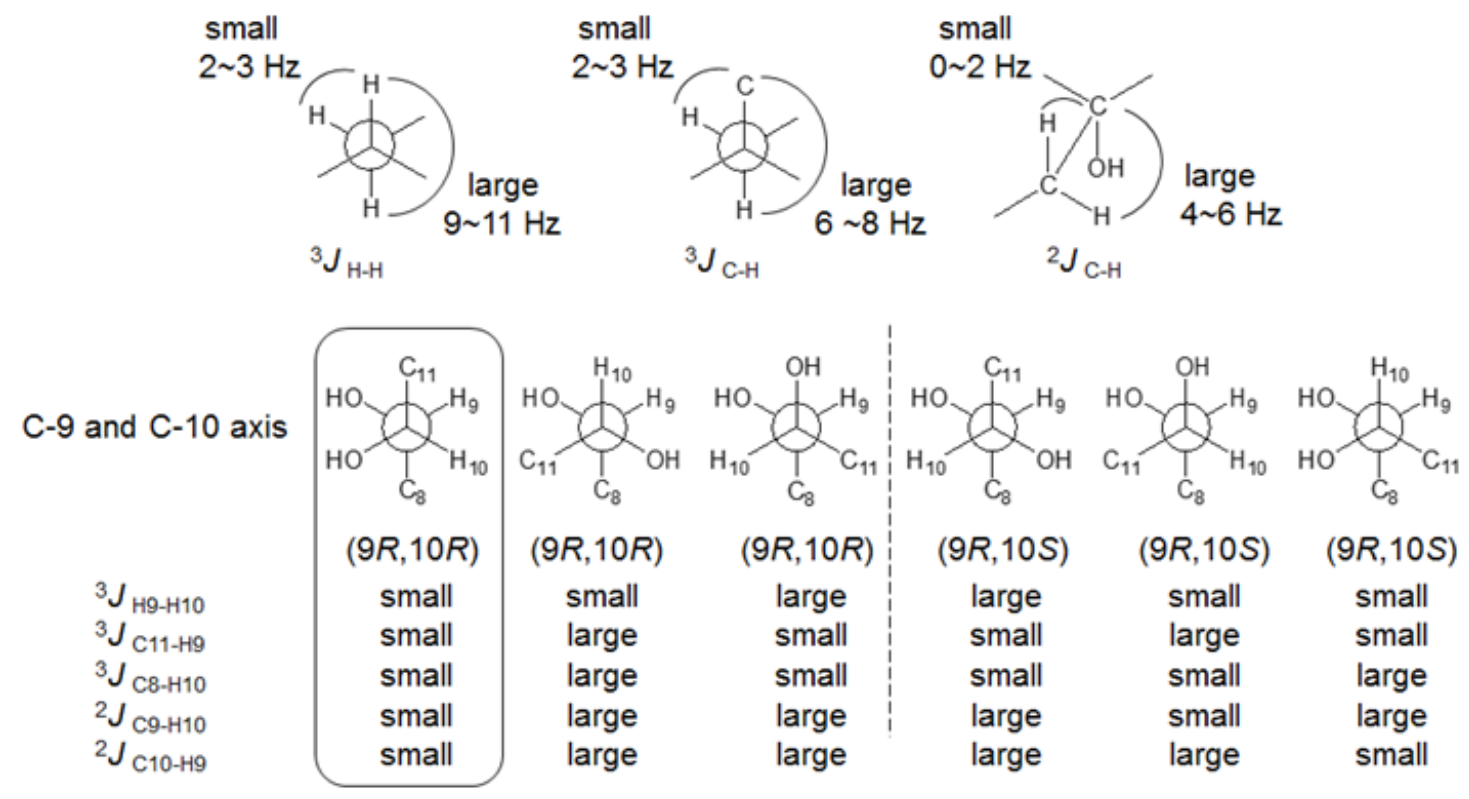

Supplementary Fig. 2. Coupling constants in the staggered system and six possible rotamers around C-9 and C-10 of $\mathbf{2 b - 2}$ 
A

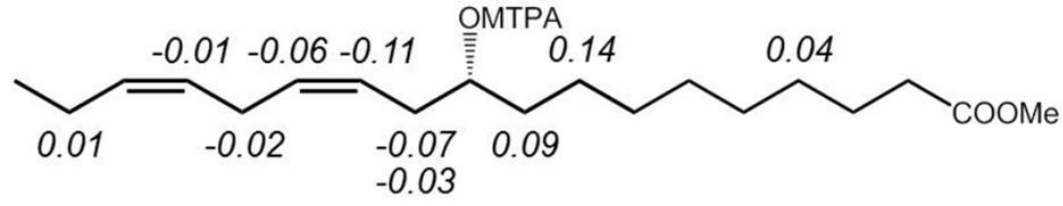

B

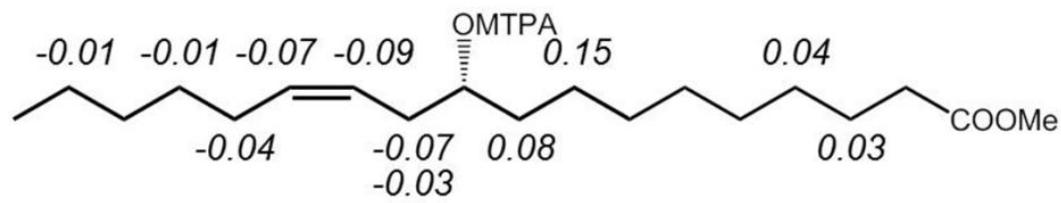

Supplementary Fig. 3. Chemical shift differences $\Delta \delta(S-R)$ of MTPA esters derived from $(R)-8(\mathrm{~A})$ and $(R)-\mathbf{1 0}$ (B) 


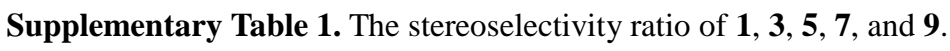

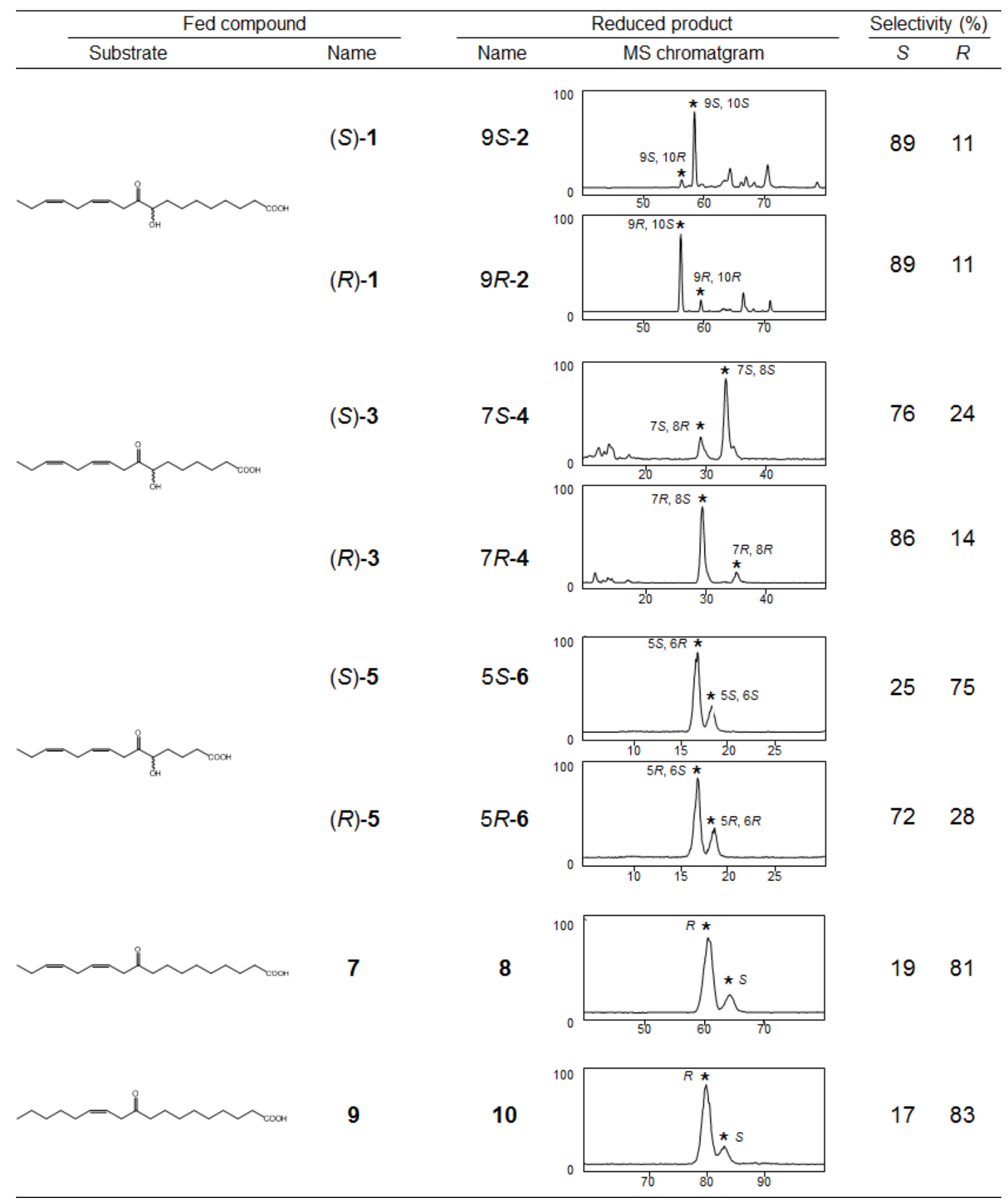


We prepared $R$ and $S$ enantiomers of $\mathbf{1}, \mathbf{3}$, and $\mathbf{5}$ and obtained corresponding diastereomeric alcohols as the authentic compouns to identify the chirality of each diol and alcohol produced by vitro experiments. The reaction mixtures after the enzymatic treatment were separated on the chiral HPLC column and detected by LC-MS.

The stereoselectivity of each respective keto-reduction was calculated based on the peak areas traced at $m / z, 311$ $[\mathrm{M}-\mathrm{H}]^{-}$for $\mathbf{2}, \mathrm{m} / z 283[\mathrm{M}-\mathrm{H}]^{-}$for $\mathbf{4}$, and $m / z, 255[\mathrm{M}-\mathrm{H}]^{-}$for $\mathbf{6}$. We prepared $\mathbf{8}$ and $\mathbf{1 0}$ from corresponding ketones 7 and 9 and determined their absolute configurations by modified Mosher's method (Fig. S3). The stereoselectivity of each respective keto-reduction was calculated based on the peak areas traced at $\mathrm{m} / z, 295$ $[\mathrm{M}-\mathrm{H}]^{-}$for $\mathbf{8}$ and $m / z, 297[\mathrm{M}-\mathrm{H}]^{-}$for $\mathbf{1 0}$. 
Supplementary Table 2. The LC-MS/MS analysis of each diastereomer of $\mathbf{4}$ and $\mathbf{6}$.

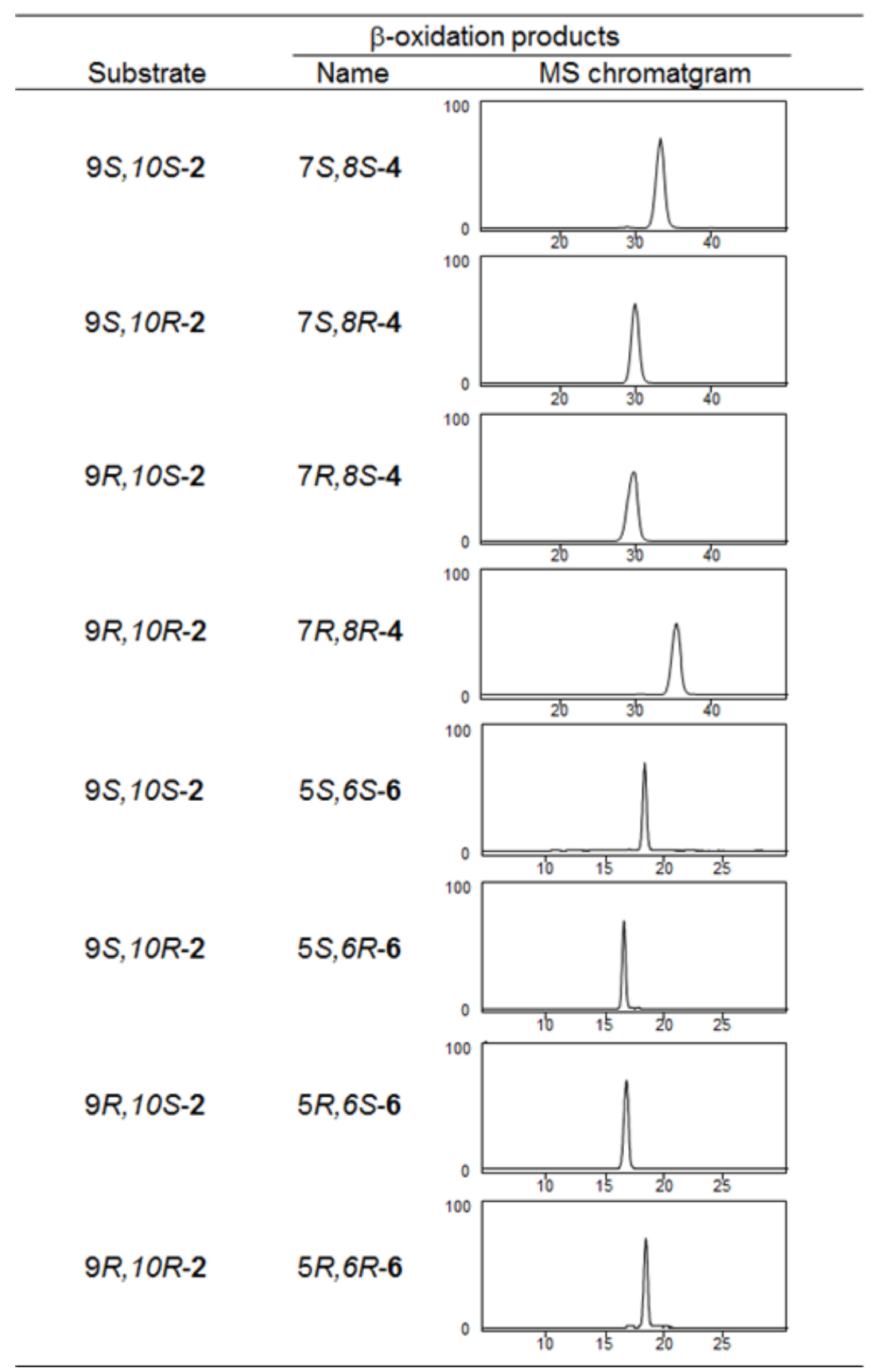


(7R,8R)-, $(7 R, 8 S)-,(7 S, 8 R)-,(7 S, 8 S)-4$ and $(5 R, 6 R)-,(5 R, 6 S)-$, $(5 S, 6 R)-$, $(5 S, 6 S)-6$ were produced from the corresponding $(9 R, 10 R)-,(9 R, 10 S)-,(9 S, 10 R)-,(9 S, 10 S)-2$ by the action of the $\beta$-oxidation enzyme. Each diaseteomer was detected by LC-MS analyses. The chromatograms are ion traces at $m / z, 283[\mathrm{M}-\mathrm{H}]^{-}$for 4, and $m / z 255[\mathrm{M}-\mathrm{H}]^{-}$for 6, respectively. Retention times were $35.6 \mathrm{~min}, 29.8 \mathrm{~min}, 29.8 \mathrm{~min}, 33.6 \mathrm{~min}$ for $(7 R, 8 R)-$, $(7 R, 8 S)^{-},(7 S, 8 R)-,(7 S, 8 S)-4$, and $18.6 \mathrm{~min}, 16.9 \mathrm{~min}, 16.9 \mathrm{~min}, 18.2 \mathrm{~min}$ for $(5 R, 6 R)-,(5 R, 6 S)-,(5 S, 6 R)-$, $(5 S, 6 S)-6$.

Enantiomers $(7 R, 8 R)-,(7 S, 8 S)-4$ and $(5 R, 6 R)-,(5 S, 6 S)-6$ were well separated each other, whereas the retention times of enantiomers $(7 R, 8 S)$ - , $(7 S, 8 R)-\mathbf{4}$ and $(5 R, 6 S)-,(5 S, 6 R)-\mathbf{6}$ were almost identical as those observed in the analyses of each diastereomer, $(9 R, 10 R)-, 9 R, 10 S)-,(9 S, 10 R)-,(9 S, 10 S)-2$. Based on these analytical data, the enantio-selective reduction of $(R)-\mathbf{3},(S)-\mathbf{3},(R)-\mathbf{5},(S)-\mathbf{5}$ were confirmed as shown in Supplementary Table 1. 